\title{
Effect of Nursing Intervention Package on Prevention of Uterine Prolapse among Pregnant Women in Third Trimester
}

\author{
Nashwa Mohammed Saeed Atallah ${ }^{1}$, Nadia Mohamed Fahmy ${ }^{2}$, Samah Abdelhalem Said ${ }^{3}$ and \\ Elham Abozied Ramadan ${ }^{4}$
}

(1) M.Sc. in Obstetric Health Nursing- Faculty of Nursing-Menoufiya University (2016), Egypt, (2) Professor of Maternal and Newborn Health Nursing, Faculty of Nursing-Ain shams University and (3,4)Assistant Professor of Obstetrics and Woman's Health Nursing- Faculty of Nursing-Benha University, Egypt

\begin{abstract}
Background: Uterine prolapse occurs when the uterus descends towards or through the opening of the vagina below its normal anatomical position. Aim of study: Was to evaluate effect of nursing intervention package on prevention of uterine prolapse among pregnant women in third trimester. Design: A quasi experimental design was utilized to fulfill the aim of the study: two groups were studied (study and control group) with pre, post and follow up test. Setting: The study was conducted at obstetrics and gynecology outpatient clinic at Benha university hospital. Sample: A purposive sample of 90 women was selected according to the inclusion criteria. Tools of data collection: Four tools were included, a structured interviewing questionnaire sheet, women's reported practices sheet toward prevention of uterine prolapse, modified Likert scale and assessment tool for uterine displacement. Results: There were a highly statistical correlation between total knowledge, total practices, and total attitude among studied women (study and control groups $)$ as $(\mathrm{p} \leq 0.000)$ and $(\mathrm{p} \leq 0.006)$.Also women who applied the nursing intervention package (study group) had no degrees of uterine prolapse in the follow up test. Conclusion: There was a highly statistical improvement in the study group than control group regarding the total level of knowledge, practice and attitude about prevention of uterine prolapse post- test. Recommendation: Develop awareness programs for the pregnant women to improve their knowledge, practice and attitude about uterine prolapse.
\end{abstract}

Key words: Attitude, Knowledge, Nursing intervention package, Practice, Uterine prolapse, Prevention.

\section{Introduction}

The uterus (womb) is a muscular structure that's held in place by pelvic muscles and ligaments. If these muscles or ligaments stretch or become weak, they're no longer able to support the uterus, causing prolapse. Uterine prolapse occurs when the uterus descends or slips from its normal position and into the vagina (birth canal) (Ernst et al., 2019).

Uterine prolapses occur when the uterus descends toward or into the vagina. It happens when the pelvic floor muscles and ligaments become weak and are no longer able to support the uterus (Smith, 2017). Prolapse can vary depending on how weak the supports of the uterus have gotten. In an incomplete prolapse, the uterus may have slipped enough to be partway in the vagina (birth canal). (Cleveland, 2021).

The main cause is injury to the ligaments and muscles, which make up the natural supporting tissue, which cradles the pelvic organs. During pregnancy, the hormonal changes and extra weight weaken the pelvic floor muscles. Pregnancy \& birth are the most common causes of weakening of the pelvic floor, particularly if the baby was large, or 
had an assisted birth (forceps/ ventouse) or prolonged labor. The more births a woman has, the more likely to develop a prolapse in later life (Wakamatsu, 2020).

Uterine prolapse is described in 4 degrees, indicating how far it has descended. Other pelvic organs (such as the bladder or bowel) may also be prolapsed into the vagina. Stage I - the uterus is in the upper half of the vagina. Stage II - the uterus has descended nearly to the opening of the vagina. Stage III - the uterus protrudes out of the vagina. Stage IV the uterus is completely out of the vagina (Chen et al 2021).

Mild uterine prolapse generally doesn't cause signs or symptoms. Signs and symptoms of moderate to severe uterine prolapse include :Sensation of heaviness or pulling in the pelvis, Tissue protruding from the vagina, Urinary problems, such as urine leakage (incontinence) or urine retention, Trouble having a bowel movement, Feeling as if sitting on a small ball or as if something is falling out of the vagina (Cathy et al., 2020).

Sexual dysfunction and changes in body image are often associated with prolapse. For some women, intercourse can be painful or the belief that their anatomy is "abnormal" may make them too embarrassed or ashamed to have sex. Women also may fear that sexual activity will cause harm to the organs involved in the prolapse (Dumoulin et al., 2014).

Risk factors include pregnancy, successive vaginal childbirth, congenital or acquired connective tissue abnormalities, Women with BMI >25 were more likely to experience uterine prolapse, connective tissue disorders such as Marfan syndrome and Ehler's Danlos syndrome. Advancing age has been shown to correlate markedly with rates of prolapse, menopause and factors associated with chronically raised intra -abdominal pressure from chronic coughing, straining with constipation, and repeated heavy lifting (Miceli \& Diez 2019).

A recent Cochrane review concluded that, conservative treatment, life style modification, pelvic floor muscle training, and kegel exercises was effective and should be considered as the first-line management of any type of uterine prolapse. Teaching a patient how to perform these exercises can be as simple as giving brief instructions in the office accompanied by a handout with guidelines and illustrations. For some women, referring to websites with appropriate information and on-line instructions can be helpful (Overby et al., 2014).

The uterus shows progressive changes during pregnancy as increased in size, myometrium become hypertrophy that means increase in size of the muscle fiber which is oestrogen effect. Hyperplasia which means increase in the number of muscle fibers which progesterone effect, However, hyperplasia is limited and the main change is due to hypertrophy. The uterus and uterine ligaments also have mechanical stretching due to hormonal and the progressive increase in fetal size inside the uterus all this changes causes uterine ligaments, muscles weakness

\section{(Johnson \& Jody 2019).}

Uterine prolapse can be prevented during pregnancy through applying the following conservative strategies such as; pelvic floor muscle training is a first line treatment and involves pulling up the pelvic floor muscles by pretending to hold in or stopping passing wind. The muscles can be strengthened by regularly doing a series of long and short holds. Also Doing kegel exercise can strengthen muscles when applied repetitively, avoid unhealthy habits such as prolonged cough, heavy lifting, long standing and squatting, avoid excessive pregnancy and labor, and following healthy life style (Bajracharya, 2016). 


\section{Aim of study}

This study was aimed to evaluate the effect of Nursing Intervention Package on Prevention of Uterine Prolapse among Pregnant Women in Third Trimester

\section{Research Hypothesis}

-Pregnant women who applied the nursing intervention package experience an improvement in knowledge, practice, attitude after application of the nursing intervention package.

- Pregnant women who applied the nursing Intervention package experienced absence of uterine prolapse than pregnant women who don't.

\section{Subject and Methods \\ Research Design}

A quasi experimental design was utilized to fulfill the aim of the study: two groups were studied (study and control group) with pre, post and follow up test.

\section{Setting}

The study was conducted at Obstetrics and Gynecology Outpatient Clinic at Benha University Hospital.

\section{Tools of data collection:}

Data was collected through using the following tools:

Tool I: A Structured interviewing questionnaire sheet designed by the researcher after reviewing related literature (GreeShma et al., 2017). It was written in an Arabic language in the form of multiple chooses questions which include the following parts:

Part 1: Socio-demographic data of the studied sample: age, residence, income, occupation, Type of family, education level (questions from 1to 5)

Part 2: Medical and surgical history for pregnant women: diabetes mellitus, hypertension, having any surgery previously (Questions from 7 to 10 )
-Obstetric history: Included menstrual history, parity, age of menarche, age of marriage, age of having 1st delivery, number of deliveries and abortion, History of using contraceptive methods (questions from 11 to 28).

Part 3: Knowledge of the studied sample about uterine prolapse:

Used to assess the women's knowledge about uterine prolapse, it consisted of 57 questions and consisted of the following parts:

The first part: General knowledge about uterine prolapse and consisted of 16 questions The second part: Knowledge about prevention of uterine prolapse during the last trimester of pregnancy, it consisted of 14 questions.

The third part: Knowledge about prevention of uterine prolapse during labor, it consisted of 10 questions.

The fourth part: Knowledge about prevention of uterine prolapse during puriperium, it consisted of 17 questions.

\section{Scoring system:}

Each item was assigned scores of (2) given when the answer was completely correct a score (1) was given when the answer was incompletely correct and a score (0) was given when the answer was unknown. These scores were converted into percent score. The total of each section of knowledge was calculated by summing of the scores of items. women's total knowledge score was classified as the following in to three categories as the following :

-Good level of knowledge $\geq 75 \%$.

-Average level of knowledge $50 \%$ - $<75 \%$.

-Poor level of knowledge $<50 \%$.

Tool II: Women's reported practices toward prevention of uterine prolapse: (Elsayed et al ,2016)

This tool used to assess women's reported practices toward prevention of uterine prolapse:

I: Before pregnancy, consisted of three questions. 
II: During pregnancy, consisted of six questions.

III: During labor, consisted of seven questions.

IV: During post -partum period consisted of six questions.

\section{Scoring system:}

Poor Practices done toke score (0)

Average Practices toke score (1)

Good practice toke score (2)

\section{The total score level was:}

Satisfactory practices $\geq 60 . \%$

Unsatisfactory practices $<60 \%$.

Tool III: Modified Likert scale: This scale composed of 16 statements modified by the researcher and used to measure the attitude of women about prevention of uterine prolapse ( Jerry et al,2017).

\section{Scoring system:}

The scoring system regarding women's answers was used as follow:

- Women who give agree answers given score 2.

- Women who give uncertain answers given score 1 .

- Women who give I disagree Answer given score 0 .

\section{These scores were converted into percent score.}

- Positive when the total score was < $75 \%$

- Negative when the total score was less than $>70 \%$

Tool IV: Assessment tool for uterine displacement, which used to assess the degree of uterine prolapse during pretest, post- test , and during follow up visit to estimate the presence of uterine prolapse or it's signs and symptoms if present (Muhammad, et al,2019) it was contained: -vaginal examination (by physician) to insure there is no uterine displacement this was used in pre, post and follow up examination .

-assess presence of uterine prolapse signs and symptoms.

-uterine prolapse degree if present in pretest, posttest or in follow up test.

Tools validity:

The validity of the tools was ascertained by a panel of three experts in the field of Obstetrics Women Health Nursing at Benha University to test content validity and according to their judgment, the questionnaire was modified and re-phrasing of sentences was made .

\section{Tool reliability:}

Tool reliability was done by cronbach's alpha coefficient (McNeish, 2017) for test internal consistency for knowledge was equal 0.927 , for practice was equal 0.946 and 0.902 for attitude.

\section{Ethical Consideration:}

Ethical aspects were considered before implementation of the study as the following : -An official permission from the study setting was obtained .

-The aim of the study was explained to each woman to gain women confidence and trust.

-The researcher took an oral consent to each woman to participate in the study and withdrawn at any time.

-The study would not cause any physical ,social ,psychological risks on the participants.

-The data was collected and treated confidentially.

-Each woman was informed about time throughout the study.

\section{Supportive materials: Instructions booklet}

The nursing intervention package (booklet) developed by the researcher after reviewing the related literature .The instructional booklet used simple Arabic language and different illustrated pictures in order to 
facilitate women understanding about uterine prolapse (definition signs and symptoms ,stages , prevention , and management ) based on the opinion of the experts and the related literature.

-The researcher used different teaching methods such as lectures, group discussion ,demonstration and role play with the assistance of the instructional booklet.

\section{Pilot study:}

-Pilot study was carried out before starting data collections on $10 \%$ of total sample, it took 6 weeks , 3 days per week.

-A 9 women were interviewed and evaluated the efficiency and clarity of the tool used for data collection and the time needed to complete structured interviewing questionnaire sheet.

-Thus Women involved in the pilot study were excluded from the main study sample.

Interviewing and assessment phase:

-Interviewing and assessment phase was conducted in both groups and starting with the control group to prevent contamination .

-For both groups at the beginning of the interview the researcher greeted the woman ,introduced herself ,explained the purpose of the study and provided the women with all information about the study (purpose ,duration, and activities ) and took oral consent of participants in the study.

-Initial assessment (pretest ) was done using assessment of the structured interview questionnaire.

-The control group received routine care by hospital staff and assessment of women's complain.

-The participant's phone number was taken by the researcher for further communication.

\section{Field work:}

Data collection was carried out from the start of March 2019 till the end of April 2020 (a period of one year) $\square$ The researcher attended at the antenatal out -patient clinic at Benha University hospital from 9.00 am to $12.00 \mathrm{pm}$ (the actual time of medical intervention in the out- patient clinics) This clinic is located at the ground floor of the out- patient building which including only room divided into diagnostic and examination area.

$\square$ The researcher visited the mentioned sitting 3times per week for study and control group. Researcher started the intervention phase with women of control group first then implement the study intervention with women of the study group to consider ethical issues of distributing care of the women.

\section{Preparatory phase:}

-During this phase ,the researcher reviewed current local and international related literature, to be more acquainted with the problem and with the tool design.

-Before implementation of the study, an official permission was obtained from the Dean of the faculty of nursing directed to ethical committee at Benha University hospital.

\section{Planning phase:}

-The program conducted to assess the Effect of Nursing Intervention Package on Prevention of Uterine Prolapse among Pregnant Women in Third Trimester.

-Based on the results obtained from pilot study and pretest assessment of women's knowledge regarding uterine prolapse to determine women's needs and knowledge defect.

-The program composed of two groups (study and control) each group composed of 45 pregnant women, each group studied for a period of 6 months.

-The program composed of nine sessions each session composed of 30 minutes, for each group. 


\section{Nashwa Mohammed, Nadia Mohamed, Samah Abdelhalem and Elham Abozied}

The women examined vaginally in 3 occasions for both groups (by the physician): First time (pre- test examination) in the initial visit to obtain the pre- test.to ensure there is no uterine displacement.

Second time (post -test examination) obtained in the eighth session with the post- test examination.

Third time (follow up examination) after delivery by 6 weeks when the women came to obtain contraceptive methods.

\section{Implementation phase :}

-The implementation phase was carried out at the previously mentioned study setting for each woman separately .

-Each woman received nine sessions the duration of each session took about 30 minutes.

-The teaching methods were included (Brain storming ,lecture , and group discussion ). In addition the researcher were able to direct the group by asking stimulating questions, listen to all questions, listen to all comments and opinions and from time to time summarizing important points.

\section{Evaluation phase}

During this phase ,all women from both groups (study ,control) came to the family planning clinic in the same setting in Benha university hospital after 6 weeks of delivery to evaluate the effect of implementation of nursing intervention package on knowledge, practice , attitude and vaginal examination and (follow up test was done ) .

\section{Limitation of the study:}

-Five women from the study sample were interviewed in the initial visit did not come back for follow up, which was replaced by another's. The researcher regains another 5 women to continue the study.
-Fear of some women from using of kegel exercise and from doing vaginal examination as it not popular and some of them fear of possible side effects on the fetus.

\section{Statistical analysis:}

-The collected data were coded, organized ,tabulated and statistically analyzed under supervision of a statistician . Qualitative data, frequency and percent distribution were calculated .For comparison between values before and after intervention package ,the Wilcox on signed ranks test $(\mathrm{Z})$ was used .For interpretation of results, $\mathrm{P}$ value $\leq 0.05$ was $\mathrm{S}$ -Descriptive statistics were applied (eg mean ,standard deviation, frequency and percentage.

-Tests of significance, (Chi square test ,Fisher Exact test ,paired $t$ test and correlation coefficient).

-A highly significant level value was considered when $\mathrm{p} \leq 0.001$.

-A significant level was considered when $\mathrm{p} \leq$ 0.005 .

-No significant level value was considered when $p>0.005$.

\section{Results:}

Table (1): Illustrates that the age of the study and control group was More than 30 years with

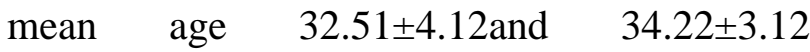
respectively In relation to educational level ,less than half of the both study and control groups had secondary education ,46.7 \% respectively. Moreover, more than half of the study and control groups were resident in rural regions $55.6 \%, 62.2 \%$, as regard occupation, more than half of the study group $53.3 \%$ were working, more than half of the control group53, $3 \%$ were house wife.

Table (2): Shows that :more than half of study and control group $55.6 \%$ and $53.4 \%$ don't know the correct knowledge about meaning of uterine 


\section{Women in Third Trimester}

prolapse and it's risk factors in pretest respectively, this result was increased in the post test to correct answers to the study group $75.6 \%$ after post- test , this percent still high after the follow up test $64.4 \%$ in the study group, which represent a highly significant difference between study and control group regarding the total knowledge items about uterine prolapse and it's risk factors $(\mathrm{p} \leq 0.000)$.

Table (3): Shows that increasing in the satisfactory practice in absence of pregnancy from pre -test to post test of study group with $60.0 \%$ in pretest to86.7 \%in post test which represent high significant value ( $\mathrm{p}$ $\leq 0.002$ ).as regard total practice during pregnancy more than half of study group represent $57.8 \%$ of satisfactory practices in pre- test , which increased in post study to $80.0 \%$ and $75.6 \%$ in the follow up test .As regard satisfactory practice during labor there is $62.2 \%$ of the pre -test satisfactory practice of the study group which enhanced in post package to $88.9 \%$ and $84.4 \%$ in follow up regarding the study group .As regard the total practice during post -partum period less than half $46.7 \%$ of the study group have satisfactory practice in the pre -test which enhanced to $86.7 \%$ in post package and $80.0 \%$ in follow up test with a highly significant different between study and control group $(\mathrm{p} \leq 0.000)$.

Table (4): Shows all women in study group and control group did vaginal examination, and nearly all women in the two groups had no symptoms of uterine prolapse except one women in the control group which had signs and symptoms of uterine prolapse and also had second degree uterine prolapse $2.2 \%$.

This table also conclude that, the women that applied the nursing intervention package (study group) has no degrees of uterine prolapse on the other side the control group which not used the nursing intervention package had a second degree of uterine prolapse in the follow up program $2.2 \%$.

Table (5): Illustrates that there is a highly statistical correlation between women's demographic characteristics (age, education level, residence, type of family and occupation) and their knowledge level as $p \leq(0.001)$.which means that there is a high knowledge level in old age ,highly educated women, in women that reside in urban than rural areas, in nuclear family than extended, and in working women than non -working women.

Table (6): Shows that there is a highly statistical correlation between total knowledge, total practices, and total attitude among studied women (study and control groups) through the program phases as $(p \leq 0.000)$ and $(p \leq 0.006)$ 
Nashwa Mohammed, Nadia Mohamed, Samah Abdelhalem and Elham Abozied

Table (1): Distribution of studied women (study and control group) regarding general characteristics $(\mathrm{N}=90)$.

\begin{tabular}{|c|c|c|c|c|c|c|}
\hline \multirow[t]{2}{*}{$\begin{array}{c}\text { Group } \\
\text { Demographic } \\
\text { characteristics }\end{array}$} & $\begin{array}{l}\text { Study } \\
\text { group } \\
(\mathrm{N}=45)\end{array}$ & \multirow[t]{2}{*}{$\%$} & $\begin{array}{l}\text { Control } \\
\text { group } \\
(\mathrm{N}=45) \\
\end{array}$ & \multirow[t]{2}{*}{$\%$} & \multirow[t]{2}{*}{$\mathrm{X} 2$} & \multirow[t]{2}{*}{$\mathrm{p}$-value } \\
\hline & No & & No & & & \\
\hline \multicolumn{7}{|l|}{ Age } \\
\hline $26-30$ & 14 & 31.1 & 9 & 20.0 & 1.460 & .227 \\
\hline More than 30 & 31 & 68.9 & 36 & 80.0 & & \\
\hline Mean \pm SD & $32.51 \pm 4.12$ & $34.22 \pm 3.12$ & & & & \\
\hline \multicolumn{7}{|l|}{ Education } \\
\hline Illiterate & 7 & 15.6 & 7 & 15.6 & 1.360 & .715 \\
\hline Basic education & 6 & 13.3 & 3 & 6.7 & & \\
\hline $\begin{array}{l}\text { secondary } \\
\text { education }\end{array}$ & 21 & 46.7 & 21 & 46.7 & & \\
\hline High education & 11 & 24.4 & 14 & 31.1 & & \\
\hline \multicolumn{7}{|l|}{ Resident } \\
\hline Rural & 25 & 55.6 & 28 & 62.2 & 0.41 & .520 \\
\hline Urban & 20 & 44.4 & 17 & 37.8 & & \\
\hline \multicolumn{7}{|l|}{ Type of family } \\
\hline Extended & 19 & 42.2 & 22 & 48.9 & 0.403 & .525 \\
\hline Nuclear & 26 & 57.8 & 23 & 51.1 & & \\
\hline \multicolumn{7}{|l|}{ Occupation } \\
\hline Working & 24 & 53.3 & 24 & 53.3 & .400 & .527 \\
\hline House wife & 21 & 46.7 & 21 & 46.7 & & \\
\hline
\end{tabular}




\section{Effect of Nursing Intervention Package on Prevention of Uterine Prolapse among Pregnant Women in Third Trimester}

Table (2): Distribution of studied women (study and control) regarding their total knowledge items about uterine prolapse and it's risk factors $: \mathrm{N}=(\mathbf{9 0})$

\begin{tabular}{|c|c|c|c|c|c|c|c|c|c|c|c|c|c|c|c|c|c|c|}
\hline \multicolumn{2}{|l|}{ Pre } & \multirow[t]{3}{*}{$\%$} & \multirow[t]{3}{*}{ No } & \multirow{3}{*}{$\begin{array}{l}\text { Control } \\
\%\end{array}$} & \multirow[t]{3}{*}{$\mathrm{X} 2$} & \multirow{3}{*}{$\begin{array}{l}\mathrm{p}- \\
\text { value }\end{array}$} & \multirow{2}{*}{\multicolumn{2}{|c|}{$\begin{array}{l}\text { Post } \\
\text { Study }\end{array}$}} & \multicolumn{2}{|c|}{ Control } & \multirow[t]{3}{*}{$\mathrm{X} 2$} & \multirow{3}{*}{$\begin{array}{l}\mathrm{p}- \\
\text { value }\end{array}$} & \multirow{3}{*}{$\begin{array}{l}\text { Follow- } \\
\text { up } \\
\text { Study } \\
\text { No }\end{array}$} & \multirow[t]{3}{*}{$\%$} & & & \multirow{3}{*}{$\mathrm{X} 2$} & \multirow{3}{*}{ p-value } \\
\hline \multirow{2}{*}{\multicolumn{2}{|c|}{ Study }} & & & & & & & & \multirow{2}{*}{ No } & \multirow{2}{*}{$\%$} & & & & & \multicolumn{2}{|c|}{ Control } & & \\
\hline & & & & & & & No & $\%$ & & & & & & & No & $\%$ & & \\
\hline \multicolumn{19}{|c|}{ Total Women's knowledge about uterine prolapse and its risk factors } \\
\hline Correct & 10 & 22.2 & 11 & 24.4 & \multirow[t]{3}{*}{0.062} & \multirow[t]{3}{*}{0.803} & 34 & 75.6 & 12 & 26.7 & \multirow[t]{3}{*}{27.88} & \multirow[t]{3}{*}{0.000} & 29 & 64.4 & 12 & 26.7 & \multirow[t]{3}{*}{12.94} & \multirow[t]{3}{*}{0.000} \\
\hline Incorrect & 10 & 22.2 & 10 & 22.2 & & & 11 & 24.4 & 10 & 73.3 & & & 10 & 22.2 & 13 & 28.9 & & \\
\hline $\begin{array}{l}\text { I don't } \\
\text { know }\end{array}$ & 25 & 55.6 & 24 & 53.4 & & & & & 23 & 51,1 & & & 6 & 13.4 & 20 & 44.4 & & \\
\hline
\end{tabular}

Table (3): Distribution of studied women (study and control) regarding their total reported practices items to prevent uterine prolapse through the program phases: $(\mathrm{N}=90)$

\begin{tabular}{|c|c|c|c|c|c|c|c|c|c|c|c|c|c|c|c|c|c|c|}
\hline \multirow[t]{3}{*}{ Items } & \multirow{2}{*}{\multicolumn{2}{|c|}{ Pre }} & \multirow{2}{*}{\multicolumn{2}{|c|}{ Control }} & \multirow[t]{3}{*}{$\mathrm{X} 2$} & \multirow[t]{3}{*}{$\begin{array}{l}\text { p- } \\
\text { value }\end{array}$} & \multirow{2}{*}{\multicolumn{2}{|c|}{$\begin{array}{l}\text { Post } \\
\text { Study }\end{array}$}} & \multirow{2}{*}{\multicolumn{2}{|c|}{ Control }} & \multirow[t]{3}{*}{$\mathrm{X} 2 \%$} & \multirow[t]{3}{*}{$\begin{array}{l}\text { p- } \\
\text { value }\end{array}$} & \multirow{2}{*}{\multicolumn{2}{|c|}{$\begin{array}{l}\text { Follow-up } \\
\% \\
\text { Study }\end{array}$}} & \multirow{3}{*}{$\begin{array}{l}\text { Control } \\
\mathrm{No}\end{array}$} & \multirow[t]{3}{*}{$\%$} & \multirow[t]{3}{*}{$\mathrm{X} 2$} & \multirow[t]{3}{*}{$\begin{array}{l}\mathrm{p} \text { - } \\
\text { value }\end{array}$} \\
\hline & & & & & & & & & & & & & & & & & & \\
\hline & No & $\%$ & No & $\%$ & & & No & $\%$ & No & $\%$ & & & No & $\%$ & & & & \\
\hline \multicolumn{19}{|c|}{ Total practices before pregnancy } \\
\hline Satisfactory & 27 & 60.0 & 25 & 55.6 & \multirow[t]{2}{*}{0.182} & \multirow[t]{2}{*}{0.670} & 39 & 86.7 & 26 & 57.8 & \multirow[t]{2}{*}{9.36} & \multirow[t]{2}{*}{0.002} & 37 & 82.2 & 25 & 55.6 & \multirow[t]{2}{*}{7.46} & \multirow[t]{2}{*}{0.006} \\
\hline Unsatisfactory & 18 & 40.0 & 20 & 44.4 & & & 6 & 13.3 & 19 & 42.2 & & & 8 & 11.8 & 20 & 44.4 & & \\
\hline \multicolumn{19}{|c|}{ Total practices During pregnancy: } \\
\hline Satisfactory & 26 & 57.8 & 25 & 55.6 & 0.045 & \multirow[t]{2}{*}{0.832} & 36 & 80.0 & 26 & 57.8 & \multirow[t]{2}{*}{5.18} & \multirow[t]{2}{*}{0.023} & 34 & 75.6 & 25 & 55.6 & \multirow[t]{2}{*}{3.98} & \multirow[t]{2}{*}{0.046} \\
\hline Unsatisfactory & 19 & 42.2 & 20 & 44.4 & & & 9 & 20.0 & 19 & 42.2 & & & 11 & 24.4 & 20 & 44.4 & & \\
\hline \multicolumn{19}{|c|}{ Total practices During labor: } \\
\hline Satisfactory & 28 & 62.2 & 27 & 60.0 & \multirow[t]{2}{*}{0.047} & \multirow[t]{2}{*}{0.829} & 40 & 88.9 & 27 & 60.0 & 9.87 & 0.002 & 38 & 84.4 & 26 & 57.8 & 7.78 & 0.005 \\
\hline Unsatisfactory & 17 & 37.8 & 18 & 40.0 & & & 5 & 11.1 & 18 & 40.0 & & & 7 & 15.6 & 19 & 42.2 & & \\
\hline Total pra & $\operatorname{aring}$ & ost p & $\mathrm{dm} \mathrm{p}$ & & & & & & & & & & & & & & & \\
\hline Satisfactory & 21 & 46.7 & 20 & 44.4 & 0.045 & 0.382 & 39 & 86.7 & 22 & 48.9 & 14.70 & 0.000 & 36 & 80.0 & 21 & 46.7 & 10.76 & 0.001 \\
\hline Unsatisfactory & 24 & 53.3 & 25 & 55.6 & & & 6 & 13.3 & 23 & 51.1 & & & 9 & 20.0 & 24 & 53.3 & & \\
\hline Total practices & & & & & & & & & & & & & & & & & & \\
\hline Satisfactory & 25 & 55.6 & 24 & 53.3 & 0.045 & 0.382 & 38 & 84.4 & 26 & 57.8 & 7.78 & 0.005 & 36 & 80.0 & 25 & 55.6 & 6.15 & 0.013 \\
\hline Unsatisfactory & 20 & 44.4 & 21 & 46.7 & & & 7 & 15.6 & 19 & 42.2 & & & 9 & 20.0 & 20 & 44.4 & & \\
\hline
\end{tabular}


Nashwa Mohammed, Nadia Mohamed, Samah Abdelhalem and Elham Abozied

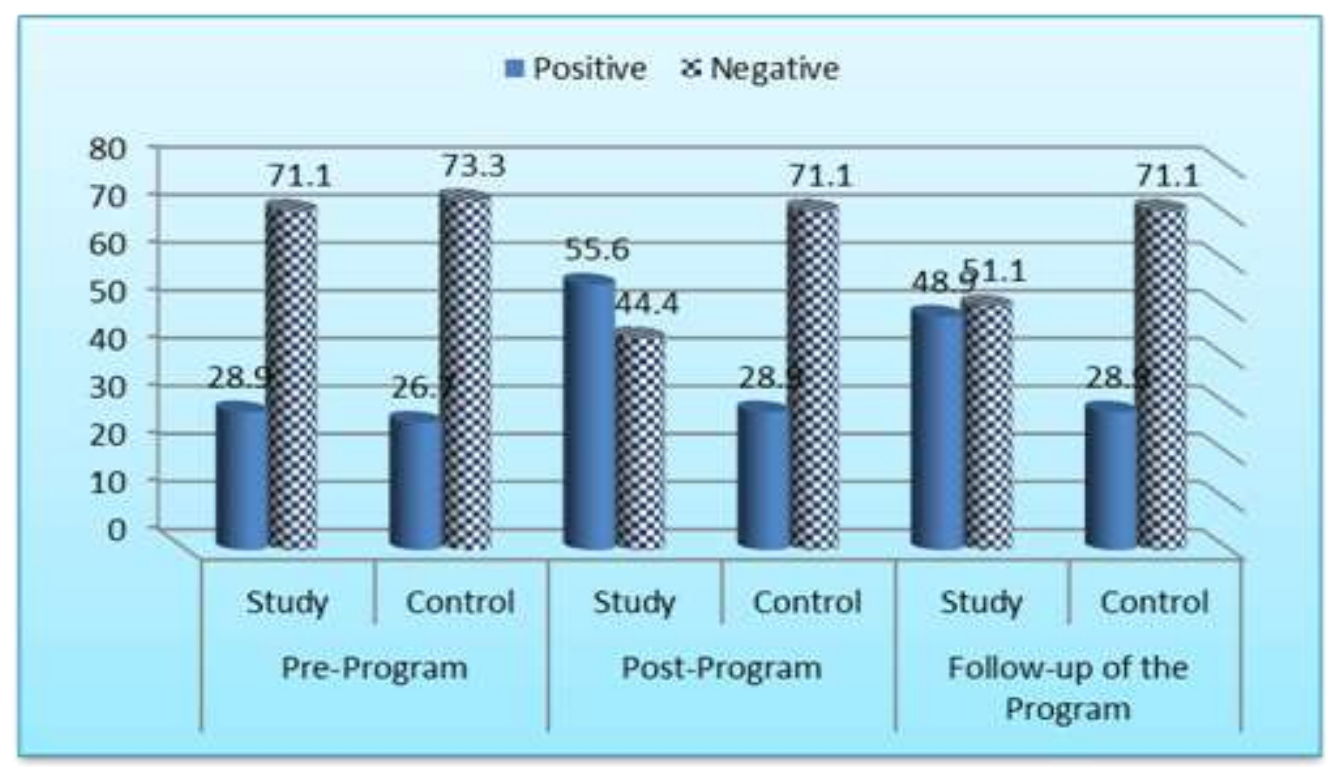

Figure (1): Percentage distribution of studied women (study and control groups) regarding their total attitude level through the program phases $(\mathrm{N}=90)$ 
Effect of Nursing Intervention Package on Prevention of Uterine Prolapse among Pregnant Women in Third Trimester

Table (4): Distribution of studied women (study and control) regarding uterine prolapse degree $(\mathbf{n = 9 0})$

\begin{tabular}{|c|c|c|c|c|c|c|c|c|c|}
\hline \multirow[t]{2}{*}{ Items } & \multicolumn{2}{|c|}{$\begin{array}{l}\text { Using (vaginal } \\
\text { examination) }\end{array}$} & \multicolumn{2}{|c|}{$\begin{array}{l}\text { Presence of Symptoms } \\
\text { of uterine prolapse }\end{array}$} & \multicolumn{2}{|c|}{$\begin{array}{l}\text { Degree of uterine } \\
\text { prolapse if present }\end{array}$} & \multirow[t]{2}{*}{ Percent } & \multirow[t]{2}{*}{ Test of significance } & \multirow[t]{2}{*}{$\mathrm{p}$-value } \\
\hline & No & $\%$ & No & $\%$ & No & & & & \\
\hline Study pre-program & 45 & 100.0 & 0 & 0.0 & 0 & 0.0 & 0 & $\mathrm{X} 21=0.000$ & 1.00 \\
\hline $\begin{array}{l}\text { control pre- } \\
\text { program }\end{array}$ & 45 & 100.0 & 0 & 0.0 & 0 & 0.0 & 0 & & \\
\hline $\begin{array}{l}\text { Study } \\
\text { program }\end{array}$ & 45 & 100.0 & 0 & 0.0 & 0 & 0.0 & 0 & $\mathrm{X} 22=11.90$ & $0.000^{* * *}$ \\
\hline $\begin{array}{l}\text { control post- } \\
\text { program }\end{array}$ & 45 & 100.0 & 0 & 0.0 & 0 & 0.0 & 0 & & \\
\hline $\begin{array}{l}\text { Study follow-up- } \\
\text { program }\end{array}$ & 45 & 100.0 & 0 & 0.0 & 0 & 0.0 & 0 & $\mathrm{X} 2=7.78$ & $0.005^{*}$ \\
\hline $\begin{array}{l}\text { Control follow-up- } \\
\text { program }\end{array}$ & 45 & 100.0 & 1 & 2.2 & Second & 1 & 2.2 & & \\
\hline
\end{tabular}
and control follow-up the program

Table (5): Correlation between total knowledge and studied women (study and control groups) demographic characteristics through program phases $(\mathrm{N}=90)$

\begin{tabular}{|c|c|c|c|c|c|c|c|c|c|c|c|c|}
\hline \multirow[t]{3}{*}{ Items } & \multirow{3}{*}{$\begin{array}{c}\text { Pre } \\
\text { Study } \\
\mathrm{R}\end{array}$} & \multirow{2}{*}{\multicolumn{2}{|c|}{ Control }} & \multirow{2}{*}{\multicolumn{2}{|c|}{$\begin{array}{c}\text { Post } \\
\text { Study }\end{array}$}} & \multirow{2}{*}{\multicolumn{2}{|c|}{ Control }} & \multirow{2}{*}{\multicolumn{2}{|c|}{$\begin{array}{c}\text { Follow-up } \\
\text { Study }\end{array}$}} & \multirow{2}{*}{\multicolumn{3}{|c|}{ Control }} \\
\hline & & & & & & & & & & & & \\
\hline & & $\begin{array}{c}\mathrm{p}- \\
\text { value }\end{array}$ & $\mathrm{R}$ & $\begin{array}{c}\mathrm{p}- \\
\text { value }\end{array}$ & $\mathrm{R}$ & $\begin{array}{c}\mathrm{p}- \\
\text { value }\end{array}$ & $\mathrm{R}$ & $\begin{array}{c}\mathrm{p}- \\
\text { value }\end{array}$ & $\mathrm{R}$ & $\begin{array}{c}\mathrm{p}- \\
\text { value }\end{array}$ & $\mathrm{R}$ & $\begin{array}{c}\mathrm{p}- \\
\text { value }\end{array}$ \\
\hline Age & .243 & .108 & .275 & .067 & .518 & $.022 *$ & .205 & .176 & .329 & $.027 *$ & .254 & .092 \\
\hline Education & .322 & $.031 *$ & .317 & $.034 *$ & .622 & $.001 * *$ & .183 & .229 & $-.164-$ & .283 & .056 & .715 \\
\hline Residence & .426 & $.003^{*}$ & .352 & $.018 *$ & .631 & .285 & .110 & .474 & $-.016-$ & .917 & .100 & .515 \\
\hline $\begin{array}{l}\text { Type of } \\
\text { family }\end{array}$ & .273 & .070 & .173 & .255 & .324 & $.030 *$ & .192 & .206 & .237 & .117 & .300 & $.046^{*}$ \\
\hline Occupation & 0.064 & .675 & .026 & .863 & .750 & $.026 *$ & .072 & .639 & .125 & .412 & .055 & .719 \\
\hline
\end{tabular}


Nashwa Mohammed, Nadia Mohamed, Samah Abdelhalem and Elham Abozied

Table (6): Correlation between total knowledge, total practices, and total attitude among studied women (study and control groups) through the program phases $(n=90)$

\begin{tabular}{|c|c|c|c|c|c|c|c|c|c|c|c|c|}
\hline \multirow{2}{*}{\multicolumn{3}{|c|}{$\begin{array}{l}\text { Knowledge } \\
\text { Pre }\end{array}$}} & \multirow{3}{*}{\multicolumn{2}{|c|}{ Control }} & \multirow{3}{*}{\multicolumn{2}{|c|}{\begin{tabular}{|l|} 
Post \\
Study
\end{tabular}}} & \multirow{3}{*}{\multicolumn{2}{|c|}{ Control }} & \multirow{3}{*}{\multicolumn{2}{|c|}{$\begin{array}{l}\text { Follow-up } \\
\text { Study }\end{array}$}} & \multirow{3}{*}{\multicolumn{2}{|c|}{ Control }} \\
\hline & & & & & & & & & & & & \\
\hline \multicolumn{3}{|l|}{ Study } & & & & & & & & & & \\
\hline \multirow[t]{2}{*}{$\begin{array}{l}\text { Total } \\
\text { practices }\end{array}$} & $\mathrm{R}$ & $\begin{array}{l}\mathrm{p}- \\
\text { value }\end{array}$ & $\mathrm{R}$ & $\begin{array}{l}\mathrm{p}- \\
\text { value }\end{array}$ & $\mathrm{R}$ & $\begin{array}{l}\mathrm{p}- \\
\text { value }\end{array}$ & $\mathrm{r}$ & $\begin{array}{l}\mathrm{p}- \\
\text { value }\end{array}$ & $\mathrm{r}$ & $\begin{array}{l}\mathrm{p}- \\
\text { value }\end{array}$ & $\mathrm{R}$ & $\begin{array}{l}\mathrm{p}- \\
\text { value }\end{array}$ \\
\hline & .213 & .160 & .361 & .151 & .799 & $.000 * *$ & .123 & .425 & .421 & $.004 *$ & .425 & $.004 *$ \\
\hline $\begin{array}{l}\text { Total } \\
\text { attitude }\end{array}$ & .074 & .631 & .494 & .512 & .402 & $.006 *$ & .139 & .362 & .509 & $.018 *$ & .208 & .169 \\
\hline
\end{tabular}


Effect of Nursing Intervention Package on Prevention of Uterine Prolapse among Pregnant

Women in Third Trimester

\section{Discussion}

The uterine prolapse is a form of pelvic organ prolapse (POP) characterized by a descent of the uterus into the vagina caused by the weakness of the endopelvic ligaments, especially the transverse ligaments. Uterine prolapse is one of the most common indications of gynecological surgery.( Shimura,2019)

The condition is most common in multiparous and post-menopausal women. The principal causes of prolapse are obstetrics trauma and post-menopausal atrophy. Carrying extra weight or physical activity increases the gravitational forces against this muscles especially in third trimester of pregnancy. Like other muscles in the body, the muscles in the pelvic floor are subject to fatigue and injury. They can also be actively exercised to increase their tone and size to prevent fatigue and injury (Priyanka et al 2015).

The present study was aimed to evaluate the effect of Nursing Intervention Package on Prevention of Uterine Prolapse among Pregnant Women in Third Trimester.

The present study was framed on the light of the study hypothesis and supported the study hypothesis (Pregnant women would experience an improvement in knowledge after application of the nursing intervention package and Intervention package would prevent uterine prolapse to pregnant women who used).

The finding of the current study would be presented under five main sections , general characteristics of the studied sample ,Women's knowledge about prevention of uterine prolapse, women's practice toward prevention of uterine prolapse, women's attitude toward prevention of uterine prolapse ,uterine prolapse assessment chart which assessed the degree of uterine prolapse .
As regard characteristics' of the studied sample, the finding of the present study revealed that, more than half of the current sample were more than 30 years age group with mean age $32.51 \pm 4.12,34.22 \pm 3.12$ years in the study and control groups respectively. Near to half of the studied women had secondary education. More than half of the study group and control group were living in ruler areas. More than half of the study and control groups are nuclear family and more than half of the study and control group were working women.

The study in line with Elsayed et al,(2016). who studied" Knowledge and practices of women regarding risk factors of uterine prolapse .,Egypt ", was stated that more than one third of the studied women were in the age group more than 30 years $36.5 \%$ with mean age of $34.46 \pm 9.017$. This finding is agreed with Bhurtel etal(2019) who studied " Knowledge on Uterine Prolapse among Reproductive Age Group Women in Nepal, India," was stated that more than half of the study sample between ages twenty five and thirty years $55.3 \%$. Majority of respondents $(72.7 \%)$ belonged to nuclear family.

This result agreed with the findings reported by Shrestha et al (2014). who studied" Knowledge on uterine prolapse among married women of reproductive age in Nepal ,India ",was reported that more than two thirds of the studied women were in age group 30-35 years The mean age of participants was $30.0 \pm 7.4$ years and $51.7 \%$ had the secondary level education.

This result is also supported by Mohammed et al, (2020). Who studied "Educational Program for Primiparous Women About Postpartum Preventive Measures of Genital Prolapse at Woman's Health Hospital ,Egypt," and reported that more than half of the 


\section{Nashwa Mohammed, Nadia Mohamed, Samah Abdelhalem and Elham Abozied}

studied sample were at secondary education level $60.4 \%$ more than three quarters respondents $(77.4 \%)$ were from rural area. This result is supported also by Nathan et al, (2017). who studied " Effectiveness of Structured Teaching Program on Knowledge Regarding Preventive Measures of Uterine Prolapse among Mothers" , and founded that more than half of the study sample were $(67.5 \%)$ of them residing in rural area. Which consistent with the current study that occurred in Qualubia governorate .The related literature illustrated that urban residing have more knowledge and educational level than rural areas, and nuclear family had more chance for education and knowledge than Extended family.

Regarding women's total knowledge about uterine prolapse and it's risk factors the finding of the current study revealed that more than two thirds of study and control group had in correct knowledge about meaning of uterine prolapse and it's risk factors in pretest by $77.8 \%$ and $75.6 \%$, this result was increased in the post test to correct answers to $75.6 \%$ in the study group compared to control group26.7 which is a highly significant difference between study and control group regarding the total knowledge items about uterine prolapse and it's risk factors.

This means that the nursing intervention package was effective in improving the women's knowledge about uterine prolapse and it's risk factors in post -test than pretest.

This finding is supported with Ibrahim etal (2018). who studied "Women's knowledge regarding pelvic organ prolapse Mansoura University, Egypt," and revealed that the majority of the studied women had inadequate knowledge regarding pelvic organ prolapse.
This finding is consistent with Okechukwu et al, (2020). who studied "Knowledge and Associated Factors of Pelvic Organ Prolapse among Women in Ebonyi State, Nigeria," and concluded that, the knowledge of risk factors and symptoms of utero vaginal prolapse was poor as less than half of the participants had adequate knowledge regarding each risk factors and symptoms of the condition study also revealed that knowledge of preventive measures of uterine prolapse was inadequate apart from knowledge of family planning and birth spacing $(60 \%)$ as preventive measure. Also, less than one-third of the study participants were not aware that surgery was a treatment modality for uterine prolapse.

This finding was in line with Maharjan et al (2019). who studied" Awareness and Knowledge about Uterine Prolapse with the use of Brochure as Health Education Tool" and concluded that ,Regarding the symptoms of UP, before the presentation of brochure $63.7 \%$ didn't know about the symptoms and after the presentation, $98.7 \%$ could cite at least two symptoms. Regarding the cause of the UP, before the presentation of the brochure, only $53.7 \%$ could tell about one cause of UP and afterwards, 100\% could remember at least 2 causes of UP. Knowledge about treatment options increased to $97.5 \%$ from only $56.2 \%$ before the presentation of the brochure. The findings of the study reflect that the use of a brochure in health education was highly effective in enhancing knowledge and awareness about UP.

This finding is supported by Mohammed et al, (2020). Who studied "Educational Program for Primiparous Women about Postpartum Preventive Measures of Genital Prolapse at Woman's Health Hospital, Egypt," this study concluded that, there was a significant improvement in knowledge 


\section{Effect of Nursing Intervention Package on Prevention of Uterine Prolapse among Pregnant}

\section{Women in Third Trimester}

regarding preventive measures of pelvic organ prolapse in post-test. Women had poor knowledge about genital prolapse; vast majority of them didn't know any knowledge about genital prolapse. The vast majority of women didn't know any preventive measures to prevent occurrence of genital prolapse.

On the country this result is inconsistent with Subedi et al,(2019). who studied " Awareness Regarding Pelvic Organ Prolapse Among Women Attending a Teaching ,Hospital in Chitwan," and concluded that more than half of the women $(65.5 \%)$ attending Gynecology out- patient clinic ,were aware regarding pelvic organ prolapsed and age of having first child was statistically significant with the level of knowledge.

This difference may be due to increase the sample age more than 40 years which increase their knowledge about obstetrics and gynecological conditions.

Regarding women's knowledge about uterine prolapse the finding of the current study revealed that there were highly statistical significant differences between both groups regarding women's knowledge, there was statistically significant improvement in the study than control groups regarding the total level of knowledge.

This finding was supported by

Elsayed et al., (2016). Who studied "Knowledge and Practices of women regarding Risk Factors of Uterine Prolapse, Egypt," and founded that, (43.5\%) did not aware about uterine prolapse. The table also exhibits that the majority of studied women had no knowledge regarding definition, risk factors (causative factors), symptoms, complication, preventive measures, treatment and degree of uterine prolapse $(56.5 \%, 73.5 \%, 80.5 \%, 85 \%, 81 \%$, $77.5 \%$, and $84.5 \%$ respectively Women had poor knowledge about uterine prolapse. Many women had never heard about uterine prolapse, most of them didn't know any knowledge about it.

The previous study finding was in the same line with Saadia, et al., (2015) who studied " effect of Maya massage on reliving uterine symptoms and degree", and reported that thirty seven percent of the studied women had low knowledge level, while fifty two percent of them had moderate level of knowledge .

On the country Bhurtel et al,(2019) who studied "Knowledge on Uterine Prolapse among Reproductive Age Group Women in Nepal," and showed that majority of respondents $(54.6 \%)$ had heard about uterine prolapse from friends. This difference may be due to difference in sample characteristics.

Regarding the practice of the study participants about prevention of uterine prolapse ,the present study revealed that ,there was statistically significant between both groups regarding total practice of prevention of uterine prolapse with a highly statistically improvement in total satisfactory practices of study participant's practices .

This result is supported by El sayed et al., (2016) who studied "Knowledge and Practices of women regarding Risk Factors of Uterine Prolapse Regarding women's practices, Egypt," that actually taken as preventive measures to prevent occurrence of uterine prolapse. The current study revealed that the majority of the studied women didn't practice or had unsatisfactory practices regarding prevention of uterine prolapse. From the researcher point of view this finding due to lack of women's knowledge and awareness as the majority of the studied women (81\%) didn't have any knowledge about preventive measures 


\section{Nashwa Mohammed, Nadia Mohamed, Samah Abdelhalem and Elham Abozied}

of uterine prolapse according the study findings.

As regard the total attitude level, the present study revealed that there is highly significant improvement in the post application of nursing intervention package than pre in the study groups from $28.9 \%$ in pre -test to 48.9 $\%$ in post -test of the study group and there is significant improvement in women's attitude in post study group than control group.

This result is supported by Baruwal et al, (2017) who studied "Knowledge, Attitude and Preventive Measures amongst Married Women of Reproductive Age Towards Uterine Prolapse in the Eight Villages of Surkhet District of Nepal," and concluded that attitude level which was not significant in the bivariate analysis, after controlling for other variables was found to be significant at the final stage of multivariate analysis at $\mathrm{p}$ value $=.049$. Two focus group discussions were carried amongst women with and without uterine prolapse to find out the factors influencing preventive behavior. It was found that though women had knowledge about the risk factors of uterine prolapse they were unable to practice risk prevention due to lack of support from family members. Gender discrimination, lack of education and awareness about one's health seems to be the root cause of it all .

This finding in line with Khanal et al,(2020) who studied "Prolapse related knowledge and attitude among married women of reproductive age ," This study revealed that almost three fourth $(70 \%)$ of respondents had low level of knowledge and only $17.6 \%$ had positive attitude regarding uterine prolapse. The level of knowledge was associated with age, occupation status and educational status. This result revealed that there is a highly statistical correlation between women's demographic characteristics (age, education level, residence, type of family and occupation ) and their knowledge level as $\mathrm{p} \leq(0.022-0.001-0.018$ $0.030-0.026$.

The present study revealed that, there is a highly statistical correlation between women's demographic characteristics (age, Education level, residence, type of family and occupation) and their knowledge level as $\mathrm{p}$ $\leq(0.022-0.001-0.018-0.030-0.026($

This finding is supportd by Rashad et al., (2018) who studied "Women's knowledge regarding pelvic organ prolapse ,Egypt, " and concluded that, there was association between women's total knowledge score regarding pelvic organ prolapse and the general characteristics of the studied women. In terms of age, education and family income, and revealed that illiterate women aged from 35$50 y e a r s$ and had inadequate family income had inadequate knowledge regarding pelvic organ prolapse.

This finding is supported with Ibrahim et al., (2018) who studied "Women's knowledge regarding pelvic organ prolapse, Egypt, " and revealed that there is association between women's total knowledge score regarding pelvic organ prolapse and the general characteristics of the studied women. In terms of age, education and family income, this study revealed that illiterate women aged from 35-50years and had inadequate family income had inadequate knowledge regarding pelvic organ prolapse.

This result inconsistent with Mohammed et al, (2020) who studied "Educational Program for Primiparous Women About Postpartum Preventive Measures of Genital Prolapse at Woman's Health Hospital, Egypt," this study revealed that, there is no association between women's total knowledge score regarding pelvic organ prolapse and the personal data of the studied women. Similarly, 


\section{Effect of Nursing Intervention Package on Prevention of Uterine Prolapse among Pregnant}

\section{Women in Third Trimester}

Shrestha et al., (2014) who studied "Knowledge on uterine Prolapse among married women of reproductive age in Nepal," who found that education and either urban or rural residence did not associate with satisfactory knowledge about Uterine prolapse, possibly due to social norms and personal perception of Uterine Prolapse. Even educated women from urban settings do not disclose Uterine Prolapse, probably due to tradition and feelings of shame in their given social context.

At the same line, Suman (2013) who studied "Effectiveness of nursing intervention package on prevention of utero-vaginal prolapse among mothers in Mangalore" and revealed that, there was no significant association of post-test knowledge score with the demographic variables such as age, religion and employment and number of children.

This result also inconsistent with Ashimi et al ,( 2014) who studied "A multicenter study on knowledge and attitude of nurses in northern Nigeria concerning female genital mutilation, Nigeria" and concluded that , The nurses studied had a high level of awareness of female genital mutilation and a good general knowledge of complications associated with female genital mutilation.

The current study Illustrated that there is a highly statistical correlation between women's demographic characteristics(age ,Education level, residence, type of family and occupation) and their knowledge level as $\mathrm{p}$ $\leq(0.001)$.which means that there is a high knowledge level in old age ,highly educated women, in women that reside in urban than rural areas, in nuclear family than extended, and in working women than non -working women.

This finding is supported by Elbiss et al (2015) who studied" Prevalence, risk factors and severity of symptoms of pelvic organ prolapse among Emirati women" And concluded that, the level of education independently determined the pre valence of pelvic organ prolapse symptoms. Surprisingly, women with university degree had less prevalence of POP symptoms compared to women with lower level of education or illiterate women. This could be due to the fact that university graduates are more aware of healthy lifestyle techniques including pelvic floor exercise com-pared to other women. Alternatively, these women tend to be more open in discussing their health issues.

This finding is inconsistent with Mohammed et al (2020) who studied "Educational Program for Primiparous Women about Postpartum Preventive Measures of Genital Prolapse at Woman's Health Hospital, Egypt," and revealed that there is no association between women's total knowledge score regarding pelvic organ prolapse and the personal data of the studied women.

The current study result revealed that, there is a statistically significant correlation between total practices and studied women (study and control groups) regarding education, resident, type of family, and occupation $(\mathrm{p} \leq 0.028),(\mathrm{p} \leq 0.040),(\mathrm{p} \leq$ $0.0421)$ and $(\mathrm{p} \leq 0.035 .0)$.

This finding is supported with Roshdy, (2013) who studied "Effect of selfguide line on reducing symptoms of first degree of uterine prolapse Egypt," who stated that there were significant positive correlation between level of women's practices about uterine prolapse and their characteristics age, educational level, knowledge before guideline and revealed also that, there were also a positive correlation between total self-care practices regarding uterine prolapse and their 


\section{Nashwa Mohammed, Nadia Mohamed, Samah Abdelhalem and Elham Abozied}

complaints before guideline and concluded that, there were a significant improvement after guideline in comparison to values before guideline.

This finding is supported also with Alharbi et al (2019) who studied "Knowledge, Attitude and Practices of Kegel Exercise among Postnatal Women, in Al Madinah Al Munawarah, Saudi Arabia" and founded that a significant relation between the participant's knowledge and some of their sociodemographic characteristics, including employment, miscarriage, level of education, and their background. Regarding the women's practice of kegel exercise; the practice was inversely correlated with age and positively correlated with the type of delivery.

The current study illustrated that, a highly positive significant correlation between total attitude and studied women (study and control groups) demographic characteristics through the program phases as ( $p \leq 0.092$. (

This finding in line with Khanal et

al, (2020) who studied "Prolapse related knowledge and attitude among married women of reproductive age , India," This study revealed that The level of attitude was associated with age, educational status and occupational status. There was significant positive relation between demographic characteristics and attitude

The current study concluded that, there were a highly statistical correlation between total knowledge, total practices, and total attitude among studied women (study and control groups) through the program phases as $(\mathrm{p} \leq 0.000)$ and $(\mathrm{p} \leq 0.006($

This result is supported with Khanal, et al, ( 2020) who studied "Prolapse related knowledge and attitude among married women of reproductive age, India ," this study revealed also that there was significant positive relation between level of knowledge and attitude $(r=0.363, p<0.001)$. The findings of this study suggest that there is an urgent need to educate and create awareness regarding UP to promote the health status of women.

The current study concluded that, the women that applied the nursing intervention package (study group) has no degrees of uterine prolapse on the other side the control group which not used the nursing intervention package had first degree of uterine prolapse in the follow up program.

This finding is supported with Farrag et al,( 2019) who studied "Evidence Based Nursing Intervention: its Effect on Relieving Women's Uterine Prolapse Symptoms and Degree, Egypt," and concluded that there is a significant improvement between pre, post and follow up percentage of women's knowledge.

This study is consistent with Pathak, (2018) who studied" Factors Associated with Uterine Prolapse among Married Women of Reproductive Age Group of Gorkha District," and concluded that , there is association between uterine prolapse and Risk factors. It was found that uterine prolapse was statistically significant with place of birth of last child ( $\mathrm{p}$ $=0.023)$, assistance of delivery $(\mathrm{p}=0.030)$, rest after delivery $(\mathrm{p}=0.019)$. Likewise, carrying heavy load after delivery $(\mathrm{p}=<0.001)$. However, types of delivery $(p=0.449)$, labor hour $(\mathrm{p}=0.513)$, severe tear of vagina in delivery $(\mathrm{p}=$ $1.00)$, place of stay after post-partum $(\mathrm{P}=1.0)$

\section{Conclusion}

There were a highly statistical significant improvement in the study group than control group regarding the total level of knowledge about prevention of uterine prolapse post- test of the nursing intervention package .As well as, there was a highly statistical significant improvement in the study group than 
Effect of Nursing Intervention Package on Prevention of Uterine Prolapse among Pregnant

Women in Third Trimester

control group regarding the total level of practice and attitude related to prevention of uterine prolapse. Moreover the women had applied the nursing intervention package (study group) had no degrees of uterine prolapse on the other side the control group which not used the nursing intervention package has second degree of uterine prolapse in the follow up program. Therefore, the study aim was achieved and the study hypotheses were supported.

\section{Recommendations}

-Develop awareness programs for the pregnant and non-pregnant women to improve their knowledge, practice and attitude about uterine prolapse.

-Raise awareness and increase knowledge of pregnant , and non- pregnant women about risk factors and aggravating factors of uterine prolapse.

Further study needs to be performed:

- Evaluate the effect of relaxation techniques on prevention of uterine prolapse .

-Evaluate the effect of healthy body mechanics on second degree uterine prolapse.

\section{References}

Alharbi JH, Alrhiely AA, Mufleh AF, Alharbi O N, Ali K, El- Sabagh ME(2019). Knowledge, Attitude and Practices of Kegel Exercise among Postnatal Women, in Al Madinah Al Munawarah, Saudi Arabia VOL 9 NO 06 (2019) doi:10.15520/ijnd.v9i06.2594

Ashimi A, Aliyu L, Shittu M , Ashimi AT and Hartman J DC, DICCP (2014). Nonsurgical Options for Treatment of Uterine Prolapse American Chiropractic Association DOI: $\quad 10.7860 / J C \quad$ DR/2017/311 80.109490 riginal

Bajracharya RA:(2016). Uterine prolapse: A hidden tragedy for women [Online]. [Nov 23]; Available from:URL: http://ww w.Shvoon g.com/me dicine and health /gynae olog $\mathrm{y} / 1711392$.

Baruwal A Color S, Biratnagar (2017). Knowledge, Attitude and Preventive Measures amongst Married Women of Reproductive Age Towards Uterine Prolapse in the Eight Villages of Surkhet District of Nepal College of Public Health Sciences, Chulalongkorn University, Bangkok, Thailand. Ratana Somronthong College of Public Health Sciences, Chulalongkorn University, Bangkok, Thailand .

Bhurtel R, Mandal R, Shah S (2019). Knowledge on Uterine Prolapse among Reproductive Age Group Women in Nepal . Nursing in Medical Surgical Nursing, subspeciality Critical Care Nursing, Lecturer, Manmohan Memorial Institute of Health Sciences, Soalteemode Kathmandu, Nepal2MN in Adult Health Nursing . ISSN: 22499571Vol.9; Issue: 11; November.

Cathy J. Chen; Thompson , H (2020). Uterine Prolapse. Last Update: November 19, 2020.

Chen CJ, Thompson H. (2021). Uterine Prolapse. StatPearls [Internet]. 2020 Nov 19.Available

from:https://www.statpearls.com/ArticleLibrary /viewarticle/30897 (accessed 4.4.2021)

Clevelandclinic,(2021).Uterine Prolapse. https://my.clevelandclinic.org/health/diseases/1 6030-uterine-prolapse.

Dumoulin C, Hunter KF, Moore K, (2014). 'Conservative management for female urinary incontinence and pelvic organ prolapse review 2013: Summary of the 5th international consultation on incontinence', Neurourology and Urodynamics, vol. 35, no. 1, pp. 1520.More information here.

Elbiss,H, Osman N ,Hammad TF (2015).Prevalence, risk factors and severity of symptoms of pelvic organ prolapse among Emirati women ,July 2015BMC Urology 
Nashwa Mohammed, Nadia Mohamed, Samah Abdelhalem and Elham Abozied

15(1):66,DOI:10.1186/s12894-015-0062-1.

United Arab Emirates University

Elsayed1F, Ahmed M, Sayed M, Gaheen A (2016). Knowledge and Practices of women regarding Risk Factors of Uterine Prolapse, Ahmed Uterine Prolapse Treatment \& Management. IOSR Journal of Nursing and Health Science (IOSR-JNHS)e-ISSN: 23201959.p- ISSN: 2320-1940 Volume 5, Issue 6 Ver. III (Nov. - Dec. 2016), PP 60 67www.iosrjournals.orgDOI:10.9790/1959050 6036067www.iosrjournals.org60Page Updated: Mar 05, 2020 .

Ernst H,Herndon J (2019). Uterine Prolapse ,Healthline, Updated on September 17, 2019.

Farrag ER , Mostafa H, Badran H (2019). Evidence Based Nursing Intervention: its Effecton Relieving Women's Uterine Prolapse Symptoms and Degree International Journal of Novel Research in Healthcare and Nursing Vol. 6, Issue 3, pp: (882-898), Month: September - December 2019, Available at: www.noveltyjournals.com

GreeShma G ,Natha N, LiNda , GheSeV, KaNmaNi J (2017). Effectiveness of Structured TeachingProgramme on KnowledgeRegarding Preventive Measures ofUterine Prolapse among Mothers.

IbrahimRM, FadelAE, El-Nemer RMA (2018).MRAWOMEN'S KNOWLEDGE REGARDING PELVICORGAN PROLAPSE, Mansoura Nursing Journal (MNJ)vol.6. No.1 ISSN:18235-2018.

Jerry LL, Chiara G,Sallies O,Laura C, Skoczylas SS, Galen S (2017). A JOG(American Journal for Obstetric and Gynecology ), Body Image in the Pelvic Organ Prolapse Questionnaire :development and Validation, El-Sevier.

Johnson, Jody E (2019). Anatomy and Physiology by Rice University, Arapahoe Community College. Anatomy and Physiology by Rice University is licensed under a Creative Commons Attribution 4.0 International License, except where otherwise noted.

Khanal,G , Ghimire P,Shrestha N , Koirala S (2020). PROLAPSE RELATED KNOWLEDGE AND ATTITUDE AMONG MARRIED WOMEN OF REPRODUCTIVE AGE.

Maharjan M, Tuladhar H,SharmaB, DwaY, Bhandari S, Maskey S, BajracharyaM, ThakurM(2019). Awareness and Knowledge about Uterine Prolapse with the use of Brochure as Health Education Tool Home / Archives / Vol 1 No 1 Journal of KIST Medical College .

McNeish, D. (2017). Thanks coefficient alpha, we'll take it from here. Psychological Methods, 23(3), 412-433. https://doi.org/10.1037/met0000144

Miceli A, Diez D JL(2019). Effectiveness of ring pessaries versus vaginal hysterectomy for advanced pelvic organ prolapse. A cohort study. Int Urogynecol J. 2019 Dec;30(12):2161-2169.

Mohammed Ali S, Mahmoud Abd-Elrahman G \& Rashad Abd-ElhafeezRE. (2020) :Educational Program for Primiparous Women About Postpartum Preventive Measures of Genital Prolapse at Woman's Health Hospital. Assiut Scientific Nursing Journal Vol (8), Issue (20), Special No.(1), pp (134-143).

MuhammadJ , Muhamad R, Rosmawati N, HusainN , Daud N, ( 2019). Pelvic Floor Muscle Exercise Education and Factors Associated with Implementation among Antenatal Women in Hospital Universiti Sains Malaysia ,Korean Journal of Family Medicine;40(1):45-52. Published online: January $7, \quad 2019.2$ DOI: https://doi.org/10.4082/kjfm.17.0136.

Nathan ,G,Varghese L ,kanmani J,(2017). Effectiveness of structured Teaching Programe on knowledge regarding preventive measures of 
Effect of Nursing Intervention Package on Prevention of Uterine Prolapse among Pregnant

Women in Third Trimester

uterine prolapse among mothers, India ,Journal of clinical and diagnostic research ,Issue 11,Qco5-Qco8.

Okechukwu B A, Johnbosco N, ChidiE, Richard L, Felix E, Edegbe O, Johnson O Obuna A, Chukwuemeka U (2020). Knowledge and Associated Factors of Pelvic Organ Prolapse among Women in Ebonyi State, Nigeria.

Overby Z, Persons R, Carrillo M (2014). Clinical inquiries: What is the best nonsurgical therapy for pelvic organ prolapse? J F Pract. 2014;63(8):471-9.

Pathak K, Khanal S (2018):Factors Associated with Uterine Prolapse among Married Women of Reproductive Age Group ofGorkha District International Journal of New Technology and Research (IJNTR)ISSN:24544116, Volume-4, Issue-3, March 2018 Pages $72-77$

Priyanka, Kaur, S., Singh, A., \& Aggrawal,N., (2015). A Pre- experimental Study to assess the Effectiveness of Nursing Intervention Package on Management of Pelvic Organ Prolapse among Women. Nursing and Midwifery Research Journal, 11(3), 131-13418.

Rashad, M., Fadel, E., El-Nemer, A., (2018). women's knowledge regarding pelvic organprolapse Mansoura Nursing Journal (MNJvol.6.No.1 ISSN:18235-2018

Roshdy , A (2013). Effectiveness of self - care guideline on reducing symptoms of first degree of uterine prolapse phd.

Saadia A., Aziz A., Randa M., Amal T: (2015). Effect of Maya massage on reliving uterine massage symptoms anddegree, Thesis Ain shams university.

Shimura K, (2019). International Journal of Gynecologic Cancer,

Shrestha B, Devkota B , Khadka BB, Choulagai B, Pahari DP, Ontas, Petzold M,
Krettek A, (2014). Knowledge on uterine prolapse among married women of reproductive age in ,Nepal (India),International Journal of women's Health ,(6), 771-779.

Smith L, (2017). What you need to know about uterine prolapse, Medical News Today. on November 22, 2017.

Subedi S, ThapaT ,Joshi A ,ChapagainS Shrestha S (2019). Awareness Regarding Pelvic Organ ProlapseAmong Women Attending a Teaching Hospital in Chitwan, india, DOI:10. 5505 lanatoljfm. 2019. 58077Anatol J Family Med 2019;2(1):33-7.

Suman T., (2013). Effectiveness of nursing intervention package on prevention of uterovaginal prolapse among mothers. Msc thesis.Mangalore.

Wakamatsu M,(2020). What to do about pelvic organ prolapse, Updated: July 2, 2020 Published: May, 2014. https://www. health.har vard.edu/womens-health/what-to-do-aboutpelvic-organ-prolapse 
تأثير حزمه من الاجراءات التمريضية علي منع حدوث السقوط الرحمي للسيدات الحوامل في الثلاثة اشهر الاخيرة للحمل

نشوي ححم سعيد عبد المقصود عطالله نادية محم فهمي - سماح عبد الحليم سعيد - الهام أبوزيد رمضان

الرحم هو هيكل عضلي يتم تثبيته في مكانه بواسطة عضلات وأربطة الحوض. إذا تمددت هذه العضلات أو الأربطة أو أصبحت ضعيفة ، فلن تعود قادرة على دعم الرحم ، مما يؤدي إلى سقوطه. يحدث سقوط فئه الرحم

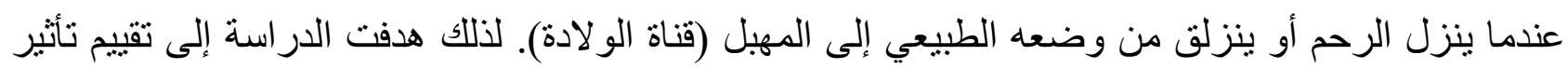
حزمة من الاجر اءات التمريضية على الوقاية من سقوط الرحم بين النساء الحوامل في الثلاثة اشهر الاخيرة

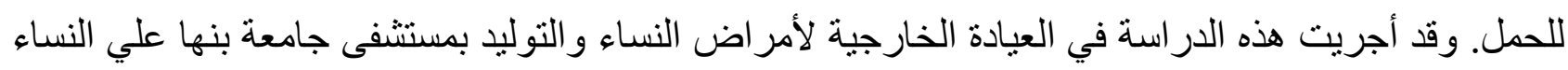

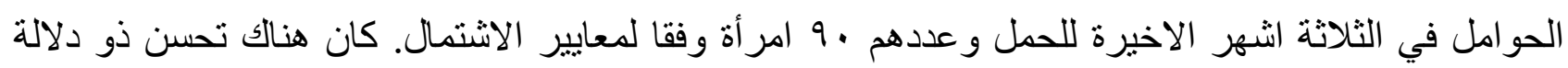

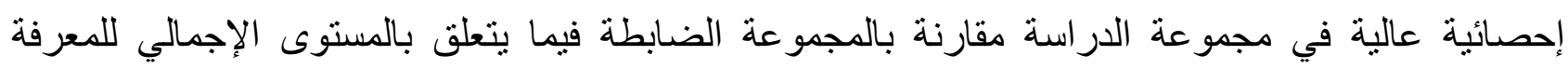

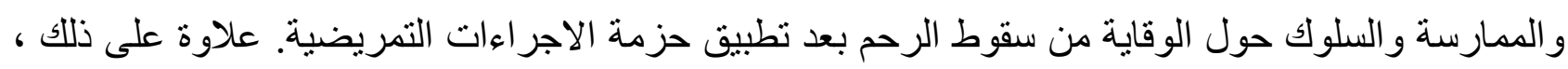

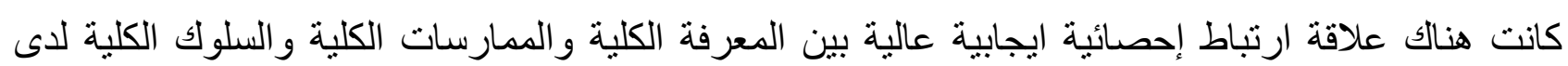

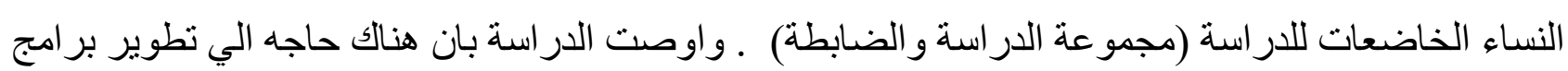

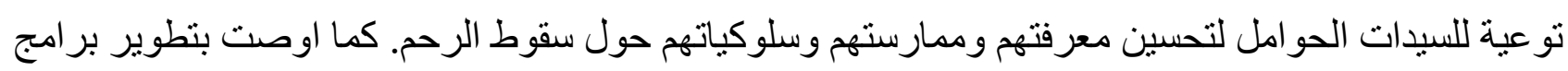
توعية للسيدات غير الحوامل في مجال الإرشاد قبل الزواج لتحسين معرفتهن وممارساتهن تجاه الوقاية من ونئن سقوط الرحم. 